IJJM

Ilomata International Journal of Management

P-ISSN: 2714-8971; E-ISSN: 2714-8963

Vol. 1 No. 3 July 2020 pp.170-178

https://www.ilomata.org/index.php/ijim

\title{
The Effect of Return on Assets (ROA), Net Profit Margin (NPM), Dividend Payout Ratio (DPR) and Dividend Yield (DY) on Stock Prices in the Subsectors tnsurance Company Listed in Indonesia Stock Exchange Period 2015-2018
}

\author{
Bustani \\ Management Study Program, Faculty of Economics \\ Kalimantan Islamic University Muhammad Arsyad Al Banjari Banjarmasin, Indonesia \\ correspondent: bustani1993@gmail.com
}

Submitted : June 27,2020 Revised : July 19,2020 Published : July 30, 2020

\begin{abstract}
This study aims to examine the effect of Return on Assets (ROA), Net Profit Margin (NPM), Dividend Payout Ratio (DPR), Dividend Yield (DY) on Share Prices in Insurance sub-sector companies listed on the Indonesia Stock Exchange period 2015- 2018. This type of research is explanatory research. This study took a population of 16 companies with a sample of 10 companies selected through purposive sampling, so the number of sample observations over 4 years to 40 companies. The data used are secondary data, namely financial statement data in the form of ROA, NPM, DPR and DY ratios from 2015-2018. Secondary data was collected through documentation of research objects obtained by the IDX. Furthermore, the data were analyzed using multiple linear regression which had previously been fulfilled the classic assumption test as a prerequisite for conducting a regression test. The results of this study ROA and NPM significantly influence stock prices. DPR and DY have no effect on stock prices. The coefficient of determination (R2)worth of $0.29 \%$, which means that the ROA, NPM, Parliament and DY explain the effect on stock prices by $29 \%$, while the value of $71 \%$ is influenced by other variables not included in this study.
\end{abstract}

Keywords: ROA, NPM, DPR and DY, Stock Price, Indonesia Stock Exchange (IDX)

\section{INTRODUCTION}

Today's global competition, every company is demanded to constantly improve company performance so that it can survive and thrive in the management of the company. Nowadays,the impact of globalization is increasing rapidly, especially companies in processing economic resources (Firdaus, 2020). Similarly, the more rapid development of insurance companies in Indonesia, the more stringent competition that occurs. The only way to survive and compete and maintain its existence in the business world is to continue to grow and develop(Egam et al., 2017). Herefore the ability of adaptation to the times must always be done so that the company still exists. One supporting factor for the company to survive and develop is the availability of funding sources. Meeting the needs for funds can be obtained by making loans in the form of debt or issuing shares in the capital market (Alipudin \& Oktaviani, 2016). Stock investment activities in the capital market are expected to generate profits for the actors (Utami \& Darmawan, 2018).

The capital market is one source of economic progress because it can be a source of capital and an alternative for companies besides banks(Astuti, 2018). ne aspect assessed by investors is financial performance (Efendi \& Ngatno, 2018; Lindriani, 2018). For this reason, when an investor invests in shares, investors need information for consideration and assessment of the company's performance and the possible effects on stock prices. There are many things that investors must do, one of which is to use fundamental analysis, which focuses on analysis- analysis of published 
The Effect Of Return On Assets (ROA), Net Profit Margin (NPM), Dividend Payout Ratio (DPR) And Dividend Yield (DY) On Stock Prices In The Subsectors Insurance Company Listed In Indonesia Stock Exchange Period 2015-2018

Bustani

financial statements. Share price is a very important factor to consider and indicators are used to measure shareholder welfare (Wulandari \& Badjra, 2019). Thus the investor's decision is very dependent on the results of the analysis of the financial statements. In this analysis investors usually use financial ratios to predict share prices, such as Return On Assets (ROA), Net Profit Margin (NPM), Dividend Payout Ratio (DPR) and Dividend Yield (DY).

Signaling theory emphasizes the importance of information released by companies on investment decisions outside parties (Bulutoding et al., 2018). Information is an important part for investors in making a decision, because with the information presented in the form of notes, information and a description of information past, present and predictions in the future can help investors make investment decisions. In making a decision, investors certainly have a variety of perspectives in interpreting information. Therefore the need for information is needed as a basis for making an investment decision. Information that illustrates good financial performance will certainly be the choice of investors, on the contrary if the company's financial performance is not good, certainly it is not possible for investors to make investment choices in companies that have poor performance. If the company performs well, of course, it is possible to get the maximum profit, if the company has a profit, of course, it allows investors to get the expected profit. Conversely, if the company does not perform well it is unlikely to get maximum profits, and investors' expectations to get profits far from expectations.

Some studies suggest different results related to Return on Assets (ROA), Net Profit Margin (NPM), Dividend Payout Ratio (DPR) and Dividend Yield (DY) on stock prices. First, Return On Assets (ROA) significantly influence stock prices (Ambarwati et al., 2019; Astuti, 2018; Bulutoding et al., 2018; Sihombing, 2019; Silalahi \& Manik, 2019; Wulandari \& Badjra, 2019). But it is different from (Alipudin \& Oktaviani, 2016; Efendi \& Ngatno, 2018; Egam et al., 2017; Hutapea et al., 2017; Lindriani, 2018; Ramdhani, 2013; Sausan et al., 2020; Utami \& Darmawan, 2018), Return On Assets has no significant effect on stock prices. Second, Net Profit Margin (NPM) has a significant effect on stock prices (Indahsafitri et al., 2015; Lindriani, 2018; Wulandari \& Badjra, 2019). But it is different from (Ambarwati et al., 2019; Astuti, 2018; Dini \& Indarti, 2012; Hutapea et al., 2017), Net Profit Margin (NPM) has no significant effect on stock prices. Third, Dividend Payout Ratio (DPR) has a significant effect on stock prices (Bulutoding et al., 2018; Devi et al., 2016; Ermiati et al., 2019; Ningrum, 2017; Nugraha \& Sudaryanto, 2016; Sihombing, 2019; Silalahi \& Manik, 2019). But it is different from (Bailia et al., 2016; Girsang et al., 2019), Dividend Payout Ratio (DPR) does not have a significant effect on stock prices. Fourth, Dividend Yield (DY) has a significant effect on stock prices Fourth, Dividend Yield (DY) has a significant effect on stock prices (Anastassia \& Firnanti, 2014; Devi et al., 2016; Ermiati et al., 2019; Margaretha, 2008; Ningsih et al., 2016; Novius, 2017; Prakoso, 2016; Wagiri, 2013). But it is different from (Puspitasari \& Purnamasari, 2013; Rachman, 2015), Dividend Yield (DY) has no significant effect on stock prices.

Based on some of the results of previous studies related (ROA, NPM, DPR and DY) on the share prices described above turned out to have different research results, so it is important for researchers to re-examine the effect of ROA, NPM, DPR and DY on stock prices in the insurance sub-sector companies listed on the Indonesia Stock Exchange (IDX) for the 2015-2018 period. 
The Effect Of Return On Assets (ROA), Net Profit Margin (NPM), Dividend Payout Ratio (DPR) And Dividend Yield (DY) On Stock Prices In The Subsectors Insurance Company Listed In Indonesia Stock Exchange Period 2015-2018

Bustani

\section{METHOD}

Type of research is explanatory research that uses a quantitative approach with the aim of testing the effect of independent variables, namely ROA, NPM, DPR and DY of the dependent variable, namely the Share Price $(\mathrm{Y})$ in the insurance sub-sector companies listed on the Indonesia Stock Exchange in the 2015-2018 period. The data used in this study are secondary data obtained on the IDX by documenting the financial statements, ROA, NPM, DPR and DY data and Share Price data taken from the summary of company performance reports listed on the IDX through the website http://www.idx.co.id, and Indonesia Capital Market Directory (ICMD) through the site http://www.finance.yahoo.com. Furthermore, the data is analyzed through multiple linear regression which was previously conducted a prerequisite test, namely the classic assumption test (Bustani \& Firdaus, 2020). This study took a population of 16 (sixteen) companies with a total sample of 10 (ten) companies selected through purposive sampling, so that the total sample of observations over 4 (four) years became 40 (forty) companies. The research model is formulated as follows (Figure 1):

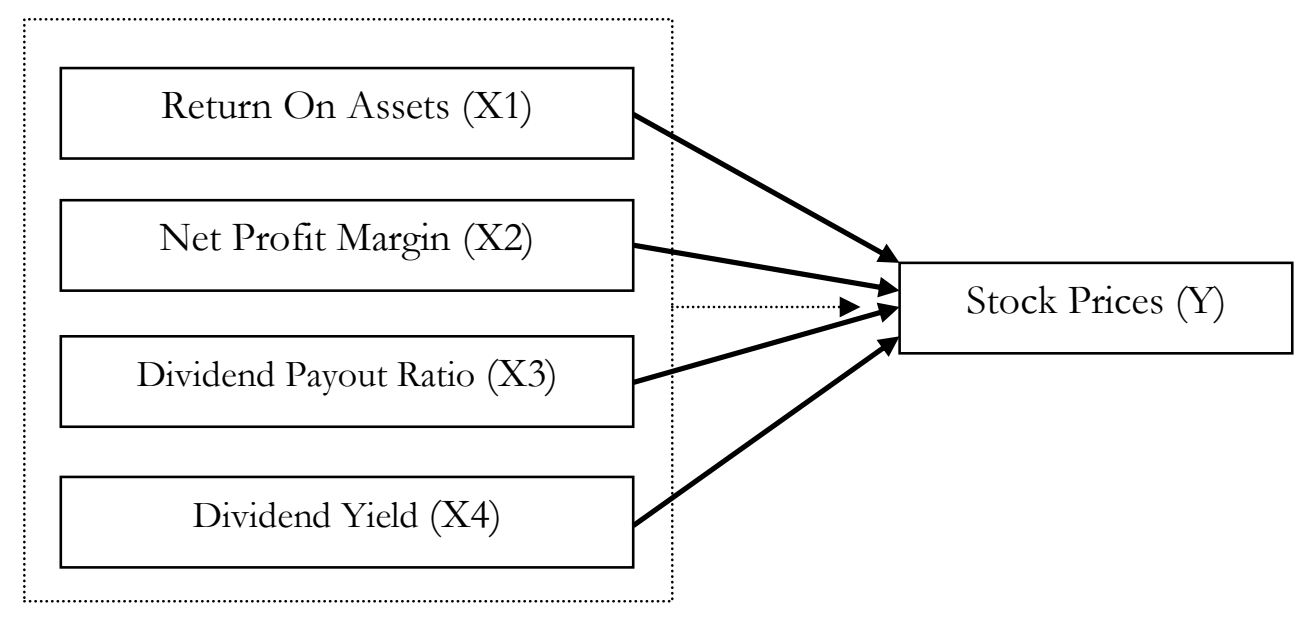

Figure 1. Research Model

Data analysis in this research uses Statistical Product and Service Solutions (SPSS) version 18 processing tools. The multiple linear regression equation in this study is formulated as follows:

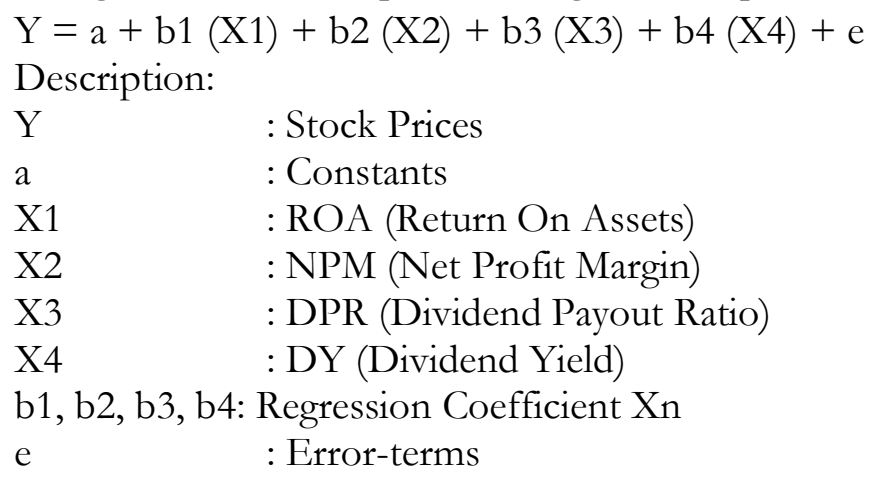

\section{RESULT AND DISCUSSION}

In this study have met the classical assumption test criteria, namely the normal distribution model, homoscedasticity has occurred, and there is no autocorrelation so the research model can proceed to regression analysis. Based on the calculation of multiple linear regression using the SPSS application version 18, the regression results of this study are shown in Table 1 below: 
The Effect Of Return On Assets (ROA), Net Profit Margin (NPM), Dividend Payout Ratio (DPR) And Dividend Yield (DY) On Stock Prices In The Subsectors Insurance Company Listed In Indonesia Stock Exchange Period 2015-2018

Bustani

Table 1. Results of Multiple Linear Regression

Coefficients $^{\mathrm{a}}$

\begin{tabular}{|c|c|c|c|c|c|c|}
\hline & \multirow{2}{*}{ Model } & \multicolumn{2}{|c|}{$\begin{array}{c}\text { Unstandardized } \\
\text { Coefficients }\end{array}$} & \multirow{2}{*}{$\begin{array}{c}\text { Standardized } \\
\text { Coefficients } \\
\text { Beta }\end{array}$} & \multirow{2}{*}{$\mathbf{T}$} & \multirow{2}{*}{ Sig. } \\
\hline & & B & $\begin{array}{l}\text { Std. } \\
\text { Error }\end{array}$ & & & \\
\hline \multirow[t]{5}{*}{1} & (Constant) & 1786,361 & 549,703 & & 3,250 & ,003 \\
\hline & Return On Assets (ROA) & 517,541 & 141,709 & ,760 & 3,652 & ,001 \\
\hline & Net Profit Margin (NPM) & $-64,790$ & 26,482 &,- 506 & $-2,447$ & ,020 \\
\hline & Dividend Payout Ratio (DPR) &, 271 &, 722 & 057 & ,376 & ,709 \\
\hline & Dividend Yield (DY) & $-224,946$ & 128,745 &,- 270 & $-1,747$ & 089 \\
\hline
\end{tabular}

a. Dependent Variable: Stock Prices

Source: Secondary data processed, 2020

From the results of multiple linear regression (Table 1), the regression equation for this study is as follows:

$$
\mathrm{Y}=1786,361+517,541(\mathrm{X} 1)-64,790(\mathrm{X} 2)+0,271(\mathrm{X} 3)-224,946(\mathrm{X} 4)
$$

Explanation of the regression equation is:

a. Constants (a) are worth 1786,361. This means that if the variable ROA, NPM, DPR and DY does not exist or is considered to have a value of 0 (zero), then the Stock Price $(Y)$ variable reaches a value of 1786,361 .

b. The coefficient value of the variable ROA (X1) is 517,541 which is positive. This shows that for every increase of 1 (one) unit on ROA with the assumption that the other independent variables are fixed, the change will raise the share price by 517,541

c. The coefficient value of the variable NPM (X2) is -64.790 which is negative. This shows that every 1 (one) unit increase in NPM with the assumption that the other independent variables are fixed, then the change will reduce the share price by $-64,790$.

d. The coefficient value of the DPR variable (X3) is 0.271 which is positive. This shows that for every increase of 1 (one) unit in the House with the assumption that the other independent variables are fixed, the change will raise the share price by 0.271 .

e. The coefficient value of the variable DY (X4) is $-224,946$ which is negative. This shows that every 1 (one) unit increase in DY with the assumption that the other independent variables are fixed, then the change will reduce the share price by $-224,946$.

Partial test (t-test) is used to see the effect of the independent variable (Xn) partially on the dependent variable $(\mathrm{Y})$. The independent variable influences the dependent variable if tcount is greater than ttable with a significance level of $5 \%$ or 0.05 . While the degree of free testing is $\mathrm{n}-\mathrm{k}$ $=40-5=35$, so that a ttable of 1.68957 is obtained. Based on the results of the t-test (Table 1 ), the partial test results of this study are as follows:

a. Variable Return On Assets(X-1)obtained tcount of 3.652 is greater than ttable 1.68957 and the significance value $0.001<0.05$, so this result proves that the hypothesis of unity (H1) is accepted. These results indicate that the Return On Assets (Xvariable1)has a significant effect on Stock Prices (Y).

b. Variable Net Profit Margin (X2)obtained tcount of -2.447 which is greater than the value of ttable -1.68957 and a significance value of $0.020<0.05$, so this result proves that the second 
The Effect Of Return On Assets (ROA), Net Profit Margin (NPM), Dividend Payout Ratio (DPR) And Dividend Yield (DY) On Stock Prices In The Subsectors Insurance Company Listed In Indonesia Stock Exchange Period 2015-2018

Bustani

hypothesis (H2) is accepted. These results indicate that the variable Net Profit Margin (X2) has a significant effect on Stock Prices $(\mathrm{Y})$.

c. Variable Dividend Payout Ratio (X3) obtained t-value of 0.376 which is smaller than t-value of table 1.68957 and significance of $0.709>0.05$, so these results prove that the third hypothesis (H3) is rejected. These results indicate that the Dividend Payout Ratio (Xvariable3)does not significantly influence the Stock Price (Y).

d. Variable Dividend Yield (X4)obtained tcount of -1.747 which is greater than t-count and significance $-1.689570 .089>0.05$, so these results prove that the fourth hypothesis $(\mathrm{H} 4)$ was rejected. These results indicate that the variables Dividend Yield (X4)partially no significant effect on stock price (Y).

Simultaneous test (F-test) is used to prove the effect of the independent variable (Xn) simultaneously on the dependent variable $(\mathrm{Y})$. F test can be obtained by determining the F- value and F-table and see the significance level of $5 \%$ or 0.05 . Degree of freedom (df) $1=4$, and (df) 2 $=35$ to obtain a f-tabel of 2.64. Then Fcount is compared with Ftable which is F-count 3,570 greater than Ftable 2.64. Thus ROA, NPM, DPR and DY simultaneously influence the price of shares in the Insurance Sub-Sector Companies Listed on the Indonesia Stock Exchange (IDX). The F-test results are shown in Table 2 below.

Table 2. Simultaneous Test Results (F-Test)

\begin{tabular}{|ll|r|r|r|r|r|}
\hline \multicolumn{2}{|l|}{ Model } & Sum of & & & \\
& & Squares & Df & Mean Square & F & \multicolumn{1}{c|}{ Sig. } \\
\hline 1 & Regression & $6,821 \mathrm{E} 7$ & 4 & $1,705 \mathrm{E} 7$ & 3,570 & , $^{\mathbf{b}}$ \\
& Residual & $1,672 \mathrm{E} 8$ & 35 & 4776997,609 & & \\
& Total & $2,354 \mathrm{E} 8$ & 39 & & & \\
\hline
\end{tabular}

Source: Secondary data processed (2020).

The coefficient of determination obtained from the analysis of this study (Table 3 ) has a value of R-square of 0.290 which means that the variation in ROA, NPM, Parliament and DY is able to explain the variations that occur in the variable Shares Price $(Y)$ by $29 \%$, while $71 \%$ of other variations are explained by other variables not included in this research model.

Table 3. Determination Coefficient

\begin{tabular}{crrrr} 
Model & R & R-square & $\begin{array}{c}\text { Adjusted R- } \\
\text { square }\end{array}$ & $\begin{array}{c}\text { Std. Error of the } \\
\text { Estimate }\end{array}$ \\
\hline 1 &, $538^{a}$ &, 290 &, 209 & 2185,63437
\end{tabular}

Sumber: Data sekunder yang diolah, 2020

Return On Assets (X1) obtained tcount of 3.652 is greater than ttable 1.68957 and the significance value $0.001<0.05$, so this result prove that the first hypothesis $(\mathrm{H} 1)$ is accepted. These results indicate that the Return On Assets (Xvariable1)partially has a significant effect on the Stock Price $(Y)$ of the Insurance Sub-Sector Companies Listed on the Indonesia Stock Exchange Period 2015-2018. These results can also be interpreted when Return On Assets increase, the Share Price will also increase. Vice versa, if Return On Assets decreases, the Stock Price will decrease as well. Thus if the Return On Assets (ROA) is high, it will be a good signal for investors. Because with high ROA shows that the company's financial performance is good, investors will be interested in investing their funds in the form of securities or shares. These findings are in line with empirical 
The Effect Of Return On Assets (ROA), Net Profit Margin (NPM), Dividend Payout Ratio (DPR) And Dividend Yield (DY) On Stock Prices In The Subsectors Insurance Company Listed In Indonesia Stock Exchange Period 2015-2018

Bustani

research (Ambarwati et al., 2019; Astuti, 2018; Bulutoding et al., 2018; Sihombing, 2019; Silalahi \& Manik, 2019; Wulandari \& Badjra, 2019) which states that Return On Assets has an effect on Stock price.

Net Profit Margin (X2) obtained tcount of -2.447 which is greater than the value of ttable 1.68957 and a significance value of $0.020<0.05$, so this result prove that the second hypothesis (H2) is accepted. These results indicate that the variable Net Profit Margin (X2) partially has a significant effect on the Stock Price (Y) of Insurance Sub Sector Companies Listed on the Indonesia Stock Exchange Period 2015-2018. These results can be interpreted when the Net Profit Margin increases, the Share Price will increase. Vice versa, if the Net Profit Margin decreases, then the Share Price will decrease as well. Thus, if the Net Profit Margin (NPM) has a significant effect on stock prices, it will be a good signal for investors. Because with a high NPM, the company's financial performance is good, investors will be interested in investing their funds in the form of securities or shares. These findings are in line with empirical research (Indahsafitri et al., 2015; Lindriani, 2018; Wulandari \& Badjra, 2019) which states that Net Profit Margin has a significant effect on Stock Prices.

Dividend Payout Ratio (X3)obtained tcount of 0.376 which is smaller than t-count and significance $1.689570 .709>0.05$, so these results prove that hypothesis third $(\mathrm{H} 3)$ is rejected. These results indicate that the Dividend Payout Ratio (Xvariable3)partially has no significant effect on the Share Price $(\mathrm{Y})$ of Insurance Sub Sector Companies Listed on the Indonesia Stock Exchange Period 2015-2018. These results can be interpreted when the Dividend Payout Ratio increases, then the Stock Price will have no effect or remain. Vice versa, if the Dividend Payout Ratio decreases, then the Share Price will also have no effect. Therefore, if the Dividend Payout Ratio (DPR) does not have a significant effect on stock prices, it will be a signal to investors that the EPS variable cannot be used as a reference in determining investors' investment strategies in investing their shares in the capital market during this research period. These findings are in line with research with (Bailia et al., 2016; Girsang et al., 2019) which states that Dividend Payout Ratio has no significant effect on stock prices.

Dividend Yield (X4)obtained tcount of -1.747 which is greater than t-count and significance $-1.689570 .089>0.05$, so these results prove that hypothesis fourth $(\mathrm{H} 4)$ received. These results indicate that the variables Dividend Yield (X4)partially no significant effect on stock price (Y) on Sub-Sector Insurance Companies Listed in Indonesia Stock Exchange Period 2015-2018. This result can be interpreted when the Dividend Yield increases, the Share Price will not increase. Vice versa, if the Dividend Yield decreases, the Share Price will not decline. Thus if the Dividend Yield (DY) does not affect the stock price then it becomes a signal for investors that the DY variable cannot be used as a reference in determining an investor's investment strategy in investing his shares in the capital market. These findings are in line with research with (Puspitasari \& Purnamasari, 2013; Rachman, 2015) which states that the Dividend Yield has no significant effect on stock prices.

\section{CONCLUSION}

Based on the results of data analysis and discussion, the Return on Assets (ROA) and Net Profit Margin (NPM) variables partially have a significant effect on stock prices. While Dividend Payout Ratio (DPR) and Dividend Yield (DY) partially do not have a significant effect on stock prices. Furthermore, the results of the analysis also prove that ROA, NPM, DPR and DY simultaneously influence stock prices. In the other test, the coefficient of determination (R2)worth 
The Effect Of Return On Assets (ROA), Net Profit Margin (NPM), Dividend Payout Ratio (DPR) And Dividend Yield (DY) On Stock Prices In The Subsectors Insurance Company Listed In Indonesia Stock Exchange Period 2015-2018

Bustani

of $0.29 \%$, which means that the Return On Assets (ROA), Net Profit Margin (NPM), Dividend Payout Ratio (DPR), Dividend Yield (DY) describe the effect on the share price of $29 \%$, while the other $71 \%$ is influenced by other variables not examined.

This study is still limited to four independent variables, namely ROA, NPM, DPR and DY which are used in this research model. The use of four independent variables is felt to still not reflect the effect on the overall stock price considering there are still other factors that influence it such as Return On Equity, Debt to Equity Ratio, Earning per Share, Company Size. This finding has practical relevance for researchers, practitioners, and investors as important information for investing in Insurance Sub-Sector Companies Listed on the Indonesia Stock Exchange. In addition, this finding can add to the repertoire of academic research, especially on the variable ROA, NPM, DPR and DY on Share Prices..

\section{REFERENCE}

Alipudin, A., \& Oktaviani, R. (2016). Pengaruh EPS, ROE, ROA Dan DER Terhadap Harga Saham Pada Perusahaan Sub Sektor Semen Yang Terdaftar di BEI. JLAFE Jurnal Ilmiah Akuntansi Fakultas Ekonomi), 2(1), 1-22. https://doi.org/10.34204/jiafe.v2i1.521

Ambarwati, P., Enas:, E., \& Lestari:, M. N. (2019). Pengaruh Net Profit Margin (NPM) dan Return On Equity (ROE) Terhadap Harga Saham (Studi Kasus Pada PT. Bank Central Asia Tbk, Yang Terdaftar Di Bursa Efek Indonesia Periode 2007-2017. Business Management and Extrepreneurship Journal, 1(2), 100-119.

Anastassia, \& Firnanti, F. (2014). Faktor-Faktor Yang Mempengaruhi Perusahaan Publik Nonkeuangan. Jurnal Bisnis Dan Akuntansi, 16(2), 95-102.

Astuti, O. D. D. (2018). Pengaruh Return on Asset (Roa) Dan Net Profit Margin (Npm) Terhadap Harga Saham Pada Perusahaan Farmasi Tbk Yang Terdaftar Di Bursa Efek Indonesia. Jurnal Ekonomi Manajemen, 4(2), 135-142. https://doi.org/10.35327/gara.v13i1.73

Bailia, F. F. W., Tommy, P., \& Baramulli, D. N. (2016). Pengaruh Pertumbuhan Penjualan, Dividend Payout Ratio Dan Debt To Equity Ratio Terhadap Harga Saham Pada Perusahaan Property Di Bursa Efek Indonesia. Jurnal Berkala Ilmiah Efisiensi, 16(3), 270-278.

Bulutoding, L., Parmitasari, R. D. A., \& Dahlan, M. A. (2018). Pengaruh Return On Asset (ROA) dan Debt To Equity Ratio (DER) Terhadap Harga Saham Dengan Kebijakan Dividen Sebagai Variabel Intervening (Studi Empiris pada Perusahaan yang Terdaftar Di Jakarta Islamic Index (JII) Periode 2010-2016). Journal of Chemical Information and Modeling, 53(9), 1689_ 1699. https://doi.org/10.1017/CBO9781107415324.004

Bustani, B., \& Firdaus, F. (2020). Pengaruh Modal Sendiri dan Volume Usaha terhadap Sisa Hasil Usaha ( SHU ) pada Koperasi Karyawan Siti Khadijah RS Islam Banjarmasin. Jurnal Maksipreneur, 10(1), 31-47.

Devi, S. K., Mardani, R. M., \& Salim, A. (2016). Pengaruh Dividen Payout Ratio (DPR), Return On Equity (ROE), Financial Leverage (FL) dan Price Earning Ratio (PER) Terhadap Harga Saham. Riset Manajemen, 1(1), 108-121.

Dini, A. W., \& Indarti, I. (2012). Pengaruh Net Profit Margin ( NPM), Return On Assets ( ROA ) Dan Return On Equity ( ROE ) Terhadap Harga Saham Yang Terdaftar Dalam Indeks Emiten LQ45 Tahun 2008 - 2010 The influence of Net Profit Margin ( NPM ), Return On Assets ( Roa ), and Return On Eq. Jurnal Kajian Akuntansi Dan Bisnis, 1(1), 1-18. 
The Effect Of Return On Assets (ROA), Net Profit Margin (NPM), Dividend Payout Ratio (DPR) And Dividend Yield (DY) On Stock Prices In The Subsectors Insurance Company Listed In Indonesia Stock Exchange Period 2015-2018

Bustani

http://jurnal.widyamanggala.ac.id/

Efendi, F. M., \& Ngatno, N. (2018). Pengaruh Return On Assets (ROA Terhadap Harga Saham dengan Earning PerShare (EPS) sebagai Intervening (Studi Kasus pada Perusahaan Sub SektorTekstil dan Garmen yang terdaftar di Bursa Efek Indonesia Periode 2013-2016). Jurnal Administrasi Bisnis, 7(1), 1. https://doi.org/10.14710/jab.v7i1.22568

Egam, G. E. Y., Ilat, V., \& Pangerapan, S. (2017). Profitability. Jurnal EMBA, 5(1), 105-114. https://doi.org/10.1007/978-1-349-15400-5_6

Ermiati, C., Amanah, D., Harahap, D. A., \& Siregar, E. S. (2019). Pengaruh Kebijakan Dividen Terhadap Harga Saham Perusahaan Sub Sektor Otomotif Dan Komponen Yang Terdaftar Di Bursa Efek Indonesia Periode 2008-2017. Niagawan, 8(2), 131-139. https://doi.org/10.24114/niaga.v8i2.14366

Firdaus, F. (2020). Effect of Total Members and Current Ratio on the Rest of Cooperative Business Result. Ilomata International Journal of Management, 1(2), 38-44.

Girsang, A. N., Tambun, H. D., Putri, A., Rarasati, D., Nainggolan, D. S. S., \& Desi, P. (2019). Analisis Pengaruh EPS, DPR, dan DER terhadap Harga Saham Sektor Trade, Services, \& Investment di BEI. Jesya Jurnal Ekonomi \& Ekonomi Syariah), 2(2), 351-362. https://doi.org/10.36778/jesya.v2i2.97

Hutapea, A. W., Saerang, I. S., Tulung, J. E., Manajemen, J., Sam, U., \& Manado, R. (2017). Pengaruh Return On Asset Net Profit Margin, Debt to Equity Ratio dan Total Aset Turnover Terhadap Harga Saham Industri Otomotif. Jurnal EMBA, 5(2), 541-551.

Indahsafitri, P. N., Wahono, B., \& Khoirul. (2015). PENGARUH RETURN ON EQUITY (ROE), NET PROFIT MARGIN (NPM), GROSS PROFIT MARGIN (GPM) DAN EARNING PER SHARE (EPS) TERHADAP HARGA SAHAM (Studi Empiris Pada Perusahaan Yang Terdaftar Dalam LQ 45 BEI Periode 2013-2016). Jurnal Riset Manajemen, 1(1), 77-97. https://doi.org/10.1123/ijsb.8.1.1

Lindriani, R. (2018). Pengaruh Return On Asset (ROA), Debt To Equity Ratio (DER), Net Profit Margin (NPM), Dan Price To Book Value (PBV) Terhadap Harga Saham Pada Perusahaan Manufaktur Sektor Industri Barang Konsumsi Yang Terdaftar Di Bursa Efek Indonesia Periode 2015-2017. Universitas Nusantara PGRI Kediri, 01(11), 1-16.

Margaretha, F. (2008). Pengaruh Price Earnings Ratio, Dividend Yield Dan Market To Book Ratio Terbadap Stock Return Di Bursa Efek. Indonesia. 10(3), 149-160.

Ningrum, N. M. W. (2017). Pengaruh Dividen Payout Ratio, Return On Asset, Return On Equity, dan Profit Margin Terhadap Harga Saham Pada Perusahaan Manufaktur Yang Terdaftar Di Bursa Efek Indonesia Tahun 2013-2015. Simci-Economic, 01(11), 1-16. https://doi.org/10.1.03.03.0022

Ningsih, V., Halim, A., \& Wulandari, R. (2016). Pengaruh Price Earning Ratio, Dividend Yield, Book To Market Ratio Danaudit Quality Terhadap Return Saham. Jurnal Riset Mahasiswa Akuntansi Unikama, 4(1), 1-13.

Novius, A. (2017). Analisis Pengaruh Kebijakan Dividen (Dividend Payout Ratio dan Dividend Yield) Terhadap Volatilitas Harga Saham (Studi Empiris Pada Perusahaan Kelompok LQ45 Yang Terdaftar di BEI). Jurnal Al-Iqtishad, 13(1), 67-77. https://doi.org/10.24014/jiq.v13i1.4389

Nugraha, R. D., \& Sudaryanto, B. (2016). Analisis Pengaruh Dpr, Der, Roe, Dan Tato Terhadap 
The Effect Of Return On Assets (ROA), Net Profit Margin (NPM), Dividend Payout Ratio (DPR) And Dividend Yield (DY) On Stock Prices In The Subsectors Insurance Company Listed In Indonesia Stock Exchange Period 2015-2018

Bustani

Harga Saham (Studi Kasus Pada Perusahaan Industri Dasar Dan Kimia Yang Terdaftar di BEI Periode 2010-2014). Management, 5(4), 1-12. http://ejournals1.undip.ac.id/index.php/management

Prakoso, R. E. (2016). Pengaruh Rasio Keuangan Terhadap Harga Saham Pada Perusahaan Manufaktur Yang Terdaftar Di Bursa Efek Indonesia Tahun 2010-2014. Jurnal Adminika, 1(1), $\quad$ 1-14. https://www.academia.edu/27935391/pengaruh_rasio_keuangan_terhadap_harga_saham_ pada_perusahaan_manufaktur_yang_terdaftar_di_bursa_efek_indonesia_tahun_2010-2014

Puspitasari, A., \& Purnamasari, L. (2013). Pengaruh Perubahan Dividend Payout Ratio Dan Dividend Yield Terhadap Return Saham (Studi Pada Perusahaan Manufaktur Di Bursa Efek Indonesia). Journal of Business and Banking, 3(2), 213. https://doi.org/10.14414/jbb.v3i2.238

Rachman, Y. H. (2015). Pengaruh Kebijakan Dividen Terhadap Harga Saham Pada Perusahaan Perbankan Yang Listed Di BEI Periode 2013-2016. Jurnal DK, 53(9), 1689-1699. https://doi.org/10.1017/CBO9781107415324.004

Ramdhani, R. (2013). Pengaruh Return on Assets dan Debt to Equity Ratio terhadap Harga Saham pada Institusi Finansial di Bursa Efek Indonesia. The Winners, 14(1), 29. https://doi.org/10.21512/tw.v14i1.642

Sausan, F. R., Korawijayanti, L., \& Ciptaningtias, A. F. (2020). The Effect of Return on Asset (ROA), Debt to Equity Ratio (DER), Earning per Share (EPS), Total Asset Turnover (TATO) and Exchange Rate on Stock Return of Property and Real Estate Companies at Indonesia Stock Exchange Period 2012-2017. Ilomata International Journal of Management, 1(2), 103-114. https://www.ilomata.org/index.php/ijtc/article/view/66

Sihombing, B. (2019). Pengaruh Dividend Payout Ratio, Return On Asset, Dan Penjualan Terhadap Harga Saham Perusahaan Manufaktur Di Bursa Efek Indonesia. Journal of Chemical Information and Modeling, 53(9), 1689-1699. https://doi.org/10.1017/CBO9781107415324.004

Silalahi, E., \& Manik, E. S. (2019). Pengaruh Dividend Payout Ratio, Debt Ratio Dan Return On Asset Terhadap Harga Saham Pada Perusahaan Manufaktur Yang Terdaftar Di Bursa Efek Indonesia. $J R A K, 5(1), 49-70$.

Utami, M. R., \& Darmawan, A. (2018). Pengaruh Der, Roa, Roe, Eps Dan Mva Terhadap Harga Saham Pada Indeks Saham Syariah Indonesia. Journal of Applied Managerial Accounting, 2(2), 206-218. https://doi.org/10.30871/jama.v2i2.910

Wagiri, W. A. (2013). Pengaruh Dividend Yield, B/M (Book To Market) Dan Earning Yield Terhadap Harga Saham Perusahaan Pada Sektor Aneka Industri Periode 2007-2011. Jurnal Ilmiah Mahasiswa Universitas Surabaya, 2(1), 1-27.

Wulandari, A. I., \& Badjra, I. B. (2019). Pengaruh Profitabilitas Terhadap Harga Saham Pada Perusahaan Lq-45 Di Bursa Efek Indonesia (Bei). E-Jurnal Manajemen Universitas Udayana, 8(9), 5722-5740. https://doi.org/10.24843/ejmunud.2019.v08.i09.p18 